\title{
Spiritual and moral training of the future kindergarten teacher in a teacher training college
}

\author{
Arkady Pankin ${ }^{1, *}$, Semen Ivanov ${ }^{2}$, Natalia Shagaeva ${ }^{1}$, Ervena Kalykova ${ }^{1}$ and Eduard \\ Sokalskiy ${ }^{1}$ \\ ${ }^{1}$ Kalmyk State University named after B.B. Gorodovikov, 11, Pushkin Str., 358000, Elista, Republic of \\ Kalmykia, Russia \\ ${ }^{2}$ Vilyuysky pedagogical College named after N.G. Chernyshevsky, 30, Chiryaev Street, 678200, \\ Vilyuisk, Republic of Sakha (Yakutia), Russia
}

\begin{abstract}
The article reveals the problems of spiritual and moral education of students of a pedagogical college located in a small city of Russia, Vilyuisk (Republic of Sakha (Yakutia). This settlement is very remote from the republican center (situated in the subarctic belt) with its rich historical past, originality and other unique characteristics. Initially, Vilyuisk was founded as a prison - a place of exile for the Decembrists, revolutionaries Poles, Social Democrats, Bolsheviks, Socialist-Revolutionaries and others (M.I. Muravyev-Apostol, P.F. Duntsov - Vygodsky, N.G. Chernyshevsky whom the teacher's college is named after, etc.). The rich heritage of the past multiplied by the present acts as a powerful stimulant in the training of the students of the Vilyuisk Pedagogical College named after N.G. Chernyshevsky for future professional activities. In this context the extraordinary potential of museum pedagogy in the training of future specialists for preschool institutions is described. For these purposes after experimental testing a multifunctional educational platform has been created on the basis of the museum of the Vilyuisk Pedagogical College named after N.G. Chernyshevsky and it has been functioning. It works effectively as a purposefully organized socio-cultural environment influencing the stimulation of the creative interests of the students, enrichment of spiritual and moral concepts and it successfully functions as an open cultural and educational environment for professional and pedagogical activities, selfdevelopment of the students. In this context a special role belongs to the laboratories: development of children's environment, "We Draw Everything", music for everyone, theater for everyone, protection of historical and cultural monuments, pedagogical researches. The students of the experimental group in addition to the general training program for specialists have attended a course of extracurricular activities on the basis of the multifunctional educational platform. The stages of the formation of the spiritual and moral qualities of the students have been diagnosed and described. As a result, the features of the dynamics of the development of spiritual and moral culture of the students of the control and experimental groups have been revealed. The innovative experience of the Vilyuisk
\end{abstract}

\footnotetext{
* Corresponding author: connotation@mail.ru
} 
Pedagogical College can be extended to other regions of the Russian Federation.

\section{Introduction}

In the Soviet Union in psychological and pedagogical theory and practice when forming a personality starting from preschool age the main emphasis was made on such characteristics as physical health, the necessary primary knowledge potential, aesthetic taste, determination and stimulation of musical inclinations; in most cases not enough, too little attention was paid to spiritual and moral education. This significant gap was mainly determined by the lack of holistic training of students-future teachers of preschool institutions. In this aspect the child's family upbringing did not compensate for the resulting gaps; later it had a negative effect in the school years. The process of self-education of an individual was also in the shadows. Such theoretical and methodological attitudes especially in the so-called period of restructuring of Soviet society "education without education" caused great damage to the younger generations. Gradually these serious omissions were overcome; primarily in educational institutions training teachers and educators for kindergartens. In this aspect the innovative experience accumulated in the Vilyuisk Pedagogical College named after N.G. Chernyshevsky (the Republic of Sakha (Yakutia) is of far from local importance. It has been successfully tested in many regions of the Russian Federation.

Upbringing of the spiritual and moral qualities of students of pedagogical colleges is a task of paramount importance - only a spiritually rich person can cultivate moral values and ideals in his pupils and mutual moral relations are the basis for the formation of the spiritual personality of a young teacher. For these purposes educational establishments use the opportunities of lesson, extracurricular and integration activities both for the purpose of teaching and forming the spiritual and moral qualities of students-future educators.

Let us comprehend from a historical perspective the thesis that the spiritual and moral education of the younger generation has occupied a key position in classical pedagogy and related fields of knowledge. At the same time our scientific search concentrates on the readiness of a young specialist (college graduate) for professional activity in a preschool educational institution.

Ya. A. Comenius in his writings and in practice called for the formation of a person in accordance with the ideals of good and social benefit [1].

I.G. Pestalozzi argued that moral education should start in the family and improve at school. The simplest moral feeling is instinctively arising in a baby's love for his mother, his "natural teacher". Education and upbringing should be carried out harmoniously, in an indissoluble connection [1].

K. D. Ushinsky [2] analyzing the works of I. Kant, J. Zh. Rousseau, J. Locke, F.E. Beneke put forward the thesis that "the first educator was the people" and came to the conclusion that the success of education and upbringing depended on taking into account the peculiarities of ethnic psychology and folk pedagogical wisdom.

According to A.S. Makarenko's moral education is based on "educating a person's abilities, on the development of his strength, his constructive, creative asset." During this period the upbringing of an individual becomes a matter of state importance requiring pedagogical attention. The ideal becomes a person- an individual that harmoniously shares his interests with the interests of the public, with the interests of his country [3].

V.A. Sukhomlinsky focuses on the creation of a personality: the upbringing of a person's spirituality and spiritual fearlessness. He writes: "The sphere of the spiritual life of the individual is expanding that is not directly related to labor, to material production. The most important of the needs of this kind is the need of a person in a person." [4]. The main thing 
in moral education is proclaimed the development of such qualities as the ability to make moral choices, to be guided by conscience, subtly, cordially feel another person, to do good and strive for beauty, independence, initiative [5].

Speaking about the problem of moral education, one cannot ignore folk pedagogy, which attaches great importance to it. In this context new ideas in spiritual and moral education are introduced by the ethnopedagogical concept of its founder - an academician G.N. Volkov [6].

In his lectures G.N. Volkov argued that "the palace of the personality is formed by four cornerstones: 1) science (knowledge) is a foundation, granite; 2) religion (faith); 3) art (beauty); 4) "education (love and example) is the largest granite stone" <... "Three sisters live in the palace: conscience, morality and spirituality" [7].

In the complex and contradictory process of personality formation starting from childhood the family plays a key role; primarily large and multigenerational one.

The special significance of the designated problems in the realities of today is determined by new scientific achievements in the field of pedagogy and related branches of knowledge under the influence of the scientific and technological revolution. Contemporary Russian scientists, in particular N.D. Nikandrov and V.I. Slobodchikov, are trying to rethink the experience of previous generations in the formation of morality, to determine its goals and content, consonant with the requirements of the XXI century.

As a result, moral and spiritual education is interpreted as a single process necessary at preschool age for further providing society with a generation capable of accepting universal human values and observing moral standards.

The research is based on the thesis that a mentor (L. S. Vygotsky, A. N. Leontiev, N. S. Leites) is the central and decisive figure in achieving the set goals. Carrying out the process of spiritual and moral education of preschoolers he appears as a person-example to follow, having a sincere interest in the results, showing flexibility and variability in the choice of methods and techniques, excluding the use of formal approaches.

The summary of the presented material allows to reveal the cardinal conditions for the upbringing of the spiritual and moral qualities of an individual: moral behavior of the teacher himself; the acquisition by children of knowledge about moral behavior; correct organization of life and activities of students, their acquisition of positive experience of moral behavior.

The aim of the presented research was to substantiate theoretically and experimentally test the effectiveness of the system of students' training of a pedagogical college for the upbringing of spiritual and moral qualities of preschoolers in the process of playing activities in a small town on the example of the Republic of Sakha (Yakutia); the possibility of extrapolation to another educational space of the Russian Federation.

\section{Materials and methods}

This research has been based on theoretical methods: historiographic, terminological, comparative analysis, method of pedagogical generalization and systematization, modeling; on empirical methods: observation, questioning, testing, generalization of experience, pedagogical design.

The instrument for measuring the level of readiness of the college students for the upbringing of spiritual and moral qualities of preschoolers in the study was V.I. Andreev's test on the self-assessment of the teacher's moral culture [8].

The presented research, analysis of the activities of an educational institution, Vilyuisk Pedagogical College named after N.G. Chernyshevsky (Republic of Sakha (Yakutia)) are unique in nature with the emphasis on the role and significance of Vilyuisk - a small town remote from the republican center, with its rich historical past, originality and other unique characteristics. At the beginning of the XIX century it received the status of the city, the administrative center of the Vilyuisk district of the Yakutsk region and served as a place of 
exile for "state criminals". It was a prison without a castle, a prison for the Decembrists, revolutionaries - Poles, Social Democrats, Bolsheviks, Socialist-Revolutionaries and others. The Decembrist M.I. Muravyov-Apostol (1828) spent more than a year in Vilyuisk. More than 10 years (since 1857) P.F. Duntsov-Vygodsky lived here. Also N.G. Chernyshevsky whom the pedagogical college was named after spent 11 years 7 months in Vilyuisk exile.

The pride of Vilyuisk is the wonderful people who were born, lived and worked in it: a well-known local history teacher, the first applicant for the Vilyuisk diamonds, Hero of Labor P.Kh. Starovatov (1873-1957), one of the first Yakut poets and scientists A.E. Kulakovsky (1877-1926), a creator of the first Yakut alphabet and the first ABC-book "Suruk - Bichik" Nikolai Novgorodov (1892-1924). A famous chemist I.L. Kondakov (1857-1931); a Yakut Soviet state, political and economic figure S.M. Arzhakov (1899-1942); a writer, a national poet of the Republic of Sakha (Yakutia), a member of the USSR Writers' Union I.M. Gogolev (1930-1998) were born in Vilyuisk [9].

Today Vilyuisk is one of the oldest cities in Yakutia. The social infrastructure is represented by 9 secondary schools, a pedagogical college named after N.G. Chernyshevsky, a vocational school. Supplementary educational institutions are Center for Scientific and Technical Creativity of Children, Children's Center "Kaskil", 2 sports schools, an art school named after MN Zhirkov, 12 kindergartens, an art school. Among the cultural institutions there is "Algys" leisure center, a folk theater, a cinema; museums: a local history museum named after P.Kh. Starovatov, a House-Museum of N.G. Chernyshevsky, a museum of public education, a museum of khomus (of national musical instruments), city and ulus newspapers are published [10]. Such a rich heritage of the past multiplied by the present works as a powerful stimulant in the training of students at the Vilyuisk Pedagogical College named after N.G. Chernyshevsky for future professional activities [11].

In the 2018-2019 academic year 545 full-time students from 24 uluses of the republic were enrolled at the college including the Arctic and northern uluses. Taking into account the correspondence course the contingent of students comprised 750 people.

Since the 2019-2020 academic year the college has increased its contingent to about 1000 students including part-time students.

Within the Agreement on strategic partnership and cooperation in the field of education, science and culture, Vilyuisk Pedagogical College named after N.G. Chernyshevsky is a base department of the Pedagogical Institute of the North-Eastern Federal University named after M.K. Ammosov (Yakutsk) and an educational and scientific base of the Pedagogy Department of the Kalmyk State University named after B.B. Gorodovikov (Elista).

Taking into account the complex of the indicated factors of an objective and subjective nature the staff of the Vilyuisk Pedagogical College determined and selected the topic of an actual scientific research and made its program.

The presented experimental work was carried out from 2016 to 2019 on the basis of the Vilyuisk Pedagogical College named after N.G. Chernyshevsky. The experiment, which included three stages, involved full-time preschool students.

At the first ascertaining stage in 201686 first-year students were asked to fill out 7 tests for self-assessment of spiritual and moral values according to the method of V.I. Andreeva. 52 students made up an experimental group (EG), 34 ones made up a control group (CG). The subjects were recruited by random sampling.

The educational process of training students is focused not only on the development of basic professional educational programs, but also on the upbringing of the spiritual and moral qualities of an individual through the system of extracurricular activities. To achieve these goals, the types and forms of supplementary education institutions are expanding from year to year, the coverage and employment of students are monitored. In addition, the educational process in the college is implemented on the basis of ideas, regulations and principles of ethnopedagogy (G.N. Volkov). 
In the system of extracurricular activities museum pedagogy is of great importance that creates an open cultural and educational environment affecting the stimulation of the creative interests of students, the enrichment of spiritual and moral concepts, the self-development of students, significantly affecting the quality of training of young graduates. This direction is based on the theory and methodology of museum pedagogy, which the student mentors have mastered. The uniqueness of the current situation lies in the fact that the college carries out its activities in a small city-museum and also has its own museum.

At the next formative stage the introduction of students to spiritual and moral values took place in various formats on the open educational platform of the Teacher's Museum, that was attended by all students of the experimental group. The diverse multi-level form of the museum's work covers all students according to their interest and allows to create a cultureforming environment for the development of an individual. In this context the established laboratories play a special role.

The third evaluative stage - final diagnostics was organized after the three-year research and was aimed at identifying the dynamics of the development of spiritual and moral culture among the students of the control and experimental groups. The students of the experimental group, in addition to the general training program for specialists, attended a course of extracurricular activities at the Teacher's Museum. Qualitative changes were determined according to V.I. Andreeva's tests among the students of the preschool department of fulltime education: 43 students of the experimental group, 28 students of the control group.

\section{Results}

The accumulated search material in accordance with the objectives of the study has been examined in detail, not only in the context of individual stages.

The analysis of the results of the first stage of the study - the assessment of the spiritual and moral development of the personality has shown that the most significant were "Family" and "Education" for the majority of the first-year students, that is quite typical for students of yesterday's entrants.

They have chosen "self-respect", "responsibility", "sociability" as characteristic features for themselves with an average score of 6.9 (above average). The freshmen consider "conscientiousness", "honesty", "mercy" as the moral qualities most inherent in them with the average test score of 4.5 (below average). We see the recent assessment characteristic of adolescents on the example of the fourth test for determining attitudes towards bad habits and qualities. So, everyone has noted the rigidity and lies with the maximum points - "10".

The average score on the test is 7.4 (above average). On the test for assessing the general culture the average score is 5.3 (average). Students have noted the positive impact of nature, music on them, the great influence of excursions and travel. On the culture of communication test the average score is 5.9 (above the average). They have rated their ability to understand another person above average (6.87 points), conversations with heart-to-heart friends, conversations about intimate. They have rated highly the culture of their relationships in the family (7.49 points). In the questionnaire for assessing the culture of moral self-development, the feeling of conscience and shame from their unpleasant actions has got the highest scores ( 7.6 points) and the desire to master the techniques of auto-training, stress relief (6.7 points). The average score for this test is 6.0 points (above average).

In the process of the formative experiment at the second stage laboratories were opened and functioned to familiarize students with spiritual and moral values. All students of the experimental group attended them. The interaction took place in various formats on the open educational platform of the Teacher's Museum.

1. One of the significant results of the project is the creation of the "Laboratory of the Development of Children's Environment". The purpose of the laboratory is to transfer to 
students scientific knowledge about the ethnopedagogical principles of the children's picture of the world. The main direction is the development of ethno toys and folk games. A toy is one of the cultural and historical universals of mankind, a means of mastering a child's own behavior. In play an adult influences the formation of children's worldview, the development of their thinking and imagination.

Within this laboratory extracurricular activities of students are organized: master classes on the author's siakhai doll (for example, based on the storyteller M.F. Prokopyeva-Nulgynet "Even fairy tales of wise Nulgynet"); folk games "Khabylyk", "Khaamyska", "Tyksaan"; making finger toys, etc.

The main results of the project: at the college the Center for the supervision and care of children of preschool age "Little Country" has been established for 25 children in conjunction with the department of preschool education; within another subproject the lost toy-doll "syakhai" has been revived.

This initiative has been successfully implemented in educational institutions of the Republic of Sakha (Yakutia); republican exhibitions-contests "Pedagogical potential of author's games and toys", "Author's doll based on folk tales and tales of Olonkho", the republican pedagogical fair "Rural school / educational brand", etc. are annually organized. Creative workshops and contests-exhibitions open up a wide field of activity for author's searches and finds.

2. Project "Draw everything". Within the project on the basis of the Teacher's Museum an agreement has been signed on joint work with the National Art Museum of the Republic of Sakha (Yakutia), that is a branch of the virtual museum "Russian Museum" in St. Petersburg. The traveling exhibitions "Listening to the World ...", an exhibition of works by students of "the Yakutsk Art School named after P.P. Romanov" were one of the first exhibitions. Of great interest among students are master classes in drawing, painting and volumetric painting by a museum employee T.A. Ivanova; as a result, there are exhibitions of student works "Artkompot", "Dawn", "Talented freshman".

3. Project "Music for All". In the vocational training of college students according to the established standards little time is devoted to music lessons. This gap is intended to fill the "Music for All" project. Its popularization is facilitated by a special exhibition stand in the main educational building of the college.

The main results of the project are partnership with the State Philharmonic of the Republic of Sakha (Yakutia) named after G. Krivoshapko - visiting concerts of soloists of the Philharmonic Society and the Art-Artiko string group; chamber performance of pedagogical college students - "Lovers of beautiful music"; a literary and musical salon; creative literary and art club "Lira"; concerts of the Children's School of Arts named after M.N. Zhirkov and others.

4. The "Theater for All" project is a means of forming future teachers. The profession of a teacher is akin to that of an actor, but a constant expenditure of internal energy, emotions, love is required from the teacher. Therefore it is necessary to develop an emotional and motivational environment for a teacher. To implement this direction the assembly hall was reorganized into a theater studio. Premises for requisites were allocated, personnel issues were resolved, an exhibition of photographs of Sakha theater artists was organized.

The main results of the project are Grand Prix of the Erbaldin student theater at the pedagogical college at the republican student festival; organization and carrying out various thematic exhibitions, excursions dedicated to memorable dates, events, phenomena; educational events - open lessons, pedagogical actions, scientific and practical conferences, thematic exhibitions, evenings, reading contests, environmental, social events.

5. Project "Protection of monuments of history and culture". In this list there is an object of cultural significance "the building of the Vilyuisk higher primary school" - now it is the Teacher's Museum. In addition, under the care of students there is a park dedicated to the 
Hero of the Soviet Union N.A. Kondakov, monuments of N.G. Chernyshevsky, M.S. Ivanov (Bagdaryin Sulbe), as well as memorial plaques dedicated to the great teachers.

To immortalize the museum's funds students have digitized the main exhibition halls of the museum and more than 2000 photographs telling about the history of the Vilyuisk Pedagogical College.

6. The project "Laboratory of Pedagogical Research" organizes the participation of students in all-Russian, republican, regional pedagogical readings, as well as student expeditions to other regions and landings in rural schools of the republic. For example, in 2018 a pedagogical expedition "Young Teacher" took place along the route Saratov-KazanCheboksary-Moscow.

In Saratov students took part in the Russian Scientific Conference of Students and Postgraduates "The Facets of History: From the Middle Ages to the Present" dedicated to the 190th anniversary of a great Russian democrat, a writer N.G. Chernyshevsky. We visited museums, historical places associated with the name of Nikolai Gavrilovich. In Kazan students got acquainted with the preparations for the World Skills International championship, talked to the students and the teachers of the Kazan Pedagogical College. Later in the capital of the Chuvash Republic, Cheboksary, the members of the pedagogical expedition visited the Pedagogical College named after a Professor, an Academician of the Russian Academy of Education, a founder of ethnopedagogy G.N. Volkov. Then round table discussions, master classes were organized for our students at the Chuvash State University named after I.N. Ulyanov, at the Research Institute of Ethnopedagogy at the Chuvash State Pedagogical University named after I. Ya. Yakovleva.

The generalized results of the third stage have shown that the students of the experimental group have had positive dynamics in improving their spiritual and moral qualities. So in comparison with the control group the average score of the test №1 - significant values of life is 8.34 (for the CG this indicator is 7.28 points). In comparison with the ascertaining stage the leaders of the most significant concepts in life instead of "family" and "education" are "love" and "career", which can be explained by the concern about finding a place for future work, and reflections on creating their own family.

In test № 2 for identifying characteristic personality traits, both groups have noted "selfrespect" and "responsibility". Separately the maximum assessment of the quality of "stress resistance" in the experimental group (10 points - maximum) has been highlighted. The classes have formed the quality of the students allowing them to more easily endure the intellectual and emotional stress caused by the peculiarities of professional activity.

Test № 3 for the development of moral qualities, both groups also have filled in the same way with a slight difference in the amplitude of manifestation of moral positive and negative qualities: EG - 7.99 and 3.7 versus CG - 7.56 and 3.25. Among the positive qualities of the EG, the quality "fairness" stands out, that has received the highest value - 9.1 (high). Among the negative qualities in both groups, the highest scores have been given to "egoism" and "arrogance". Separately it is worth noting the "cowardice" indicator in the EG (4.7 - below the average). The students of this group have determined this quality for their moral selfimprovement as a necessary condition for their professional development, the ability to cope with their fear (fear of performance, audience, classes with children, etc.).

Test № 4 for attitude to bad habits and qualities has revealed a significant difference in the average scores of this test in the CG - 7.4 (above average) and in the EG - 5.2 (average). We believe that this is explained by a more conscious attitude to psychoemotional portraits of children and adults, the emerging professional literacy among students of the EG.

In test № 5 for self-assessment of general moral culture the EG significantly have increased the role and positive influence from visits to exhibitions, museums, excursions, travel, the degree of influence of their hobbies on the development of the spiritual and moral 
sphere. The disadvantage is the decrease in reading of fiction in the EG, that may be a consequence of the excessive employment of students.

The difference between the average score of the test for the culture of communication (moral aspect, Test № 6) and the test of the culture of moral self-development (Test № 7) are insignificant: in the CG - 5.9 and 6.0 (above average), in the EG - 6.9 and 7.0 (above average) respectively. From the general number of similar answers in the EG the degree of striving to change oneself for the better in moral terms stands out.

The average score of the self-assessment test of moral culture of future teachers has shown that the students of the control group have had 6.5 points (above the average), and 7.6 (above the average) points in the experimental group.

The second level of the third stage has provided evidence-based testing of the hypothesis, has included a detailed study of the methodology of gaming technologies by students using a portfolio. Students of the control group (28 people) and students of the experimental group (43 people) took part in the compilation of the portfolio of games who participated in the approbation of the model of an open educational platform based on the Teacher's Museum.

The portfolios of games were tested by observation in the process of playing activities of pupils of the senior preparatory group of the preschool educational institution "Kuobakhchaan" in Vilyuisk.

\section{Discussion}

The analysis of the results of the first stage of the research has revealed the average level of spiritual and moral qualities of the first-year students of the preschool education. The obtained experimental data allow to conclude that the surveyed students have a strong motivation to study, they show humanistic principles and qualities that correspond to educators, such as responsibility, sociability, honesty, mercy, intransigence to rigidity, rudeness.

Based on the results of this stage in order to develop the spiritual and moral qualities of students and to train them for professional activity a project has been developed to create an open educational platform on the basis of Vilyuisk Pedagogical College named after N.G. Chernyshevsky. It has provided conditions for revealing creative potential, creative thinking, expanding the possibilities of professional and personal self-realization, and self-education.

The purpose of the project is to help students familiarize themselves with the complex tasks of shaping the world of spiritual and moral culture. Another function of the designated pedagogical innovation is an experimental platform for studying the problems of moral and aesthetic perception, creative and spiritual development. In addition, this open educational platform in a small town more widely realizes the possibilities of educational institutions, cultural institutions and society in shaping the worldview of the modern young generation.

The educational platform of the Teacher's Museum effectively works as a reasonably organized socio-cultural environment that influences the stimulation of students' creative interests, enrichment of spiritual and moral concepts and successfully functions as an open cultural and educational environment for professional and pedagogical activities, selfdevelopment of students.

At the next formative stage the introduction of students to spiritual and moral values took place in various formats on the open educational platform of the Teacher's Museum, that was attended by all participants in the experimental group. The diverse multi-level form of the museum's work covers all students of interest and allows you to create a culture-forming environment for the development of personality. In this context, the established laboratories play a special role.

The organization of the third assessment stage made it possible to identify the positive changes in the spiritual and moral qualities of the students of both groups. At the same time 
the greatest changes affected the students of the experimental group, engaged by classes in the open educational platform of the college museum. Feedback from teachers and the characteristics of curators of students in this group show significant changes in personal qualities, active participation in the public life of the college and the city, success in educational and extracurricular activities.

At the second level of the third stage of the conducted scientific research it turned out that the quality of the games of the students of the experimental group in comparison with the control group differed in content and plot. Most of the developed projects are of an author's or rationalization character based on folk games and toys, are less regulated, and contain a field for the development of imagination and creativity.

For the graduates of the Vilyuisk Pedagogical College the creation of such portfolios of gaming technologies has become one of the essential pedagogical conditions for professional growth.

\section{Conclusions}

The current results indicate that in pedagogical colleges in the conditions of a small town with an insufficient infrastructure of cultural and educational institutions and with limited opportunities for the socio-cultural environment, the development of spiritual and moral values of future kindergarten teachers will be more productive when creating organizational and pedagogical conditions of an innovative nature. One of them is the organization and functioning of an open educational platform at the college on the basis of existing museums or centers. The creative nature and variety of forms of classes allow students to reveal their individual abilities with different personal abilities and preferences. In such an educational situation students have an opportunity to cultivate analytical, organizational, communicative, creative abilities and develop their spiritual and moral qualities.

As a result, the above-mentioned pedagogical innovations give the right to substantiate the conclusions that the structures of supplementary education of the college can provide effectively and variedly the content of the main curriculum, primarily in the spiritual and moral sphere of the individual forming professional competencies. It leads, in particular, to the development of individual educational routes of the educational process at college.

The developed and tested innovations can be extrapolated to secondary vocational educational institutions in other regions of the country taking into account their specifics.

\section{References}

1. Ya.A. Comenius, J. Locke, Zh. Rousseau, I.G. Pestalozzi, Pedagogicheskoe nasledie (Moscow, Pedagogika, 1987)

2. K.D. Ushinskiy, O vospitanii (Moscow, Shkol'naya Pressa, 2003)

3. A.S. Makarenko, O kommunisticheskoj jetike Hrestomatiya po pedagogike (Moscow, Prosveshhenie, 1976)

4. V.A. Sukhomlinskiy, Potrebnost' cheloveka v chelove (1978)

5. V.A. Sukhomlinskiy, Pavlyshskaya srednyaja shkola. Hrestomatiya po pedagogike (Moscow, Prosveshhenie, 1976)

6. G.N. Volkov, Pedagogika natsional'nogo spaseniya: izbrannye etnopedagogicheskie sochineniya (Elista, APP "Dzhangar", 2003)

7. A.A. Sokal'skij, E.A. Sokal'skij, Kalmytskaya osen' akademika G.N. Volkova (Elista, Izdatel'stvo Kalmytskogo gosudarstvennogo universiteta, 2014) 
8. V.I. Andreev, Pedagogicheskaya jetika: innovatsionnyj kurs dlya nravstennogo samorazvitiya (Kazan', Tsentr innovatsionnyh tehnologij, 2012)

9. P.P. Petrov, N.S. Mironov, Vilyuiskij ulus: istoriya, kul'tura, fol'klor (Yakutsk, Bichik, 2009)

10. U.F. Kondakova, K.K. Lukina, Vilyuiskaya zemlya: istoki, traditsii, sovremennost' (Yakutsk, Bichik, 2014)

11. U.F. Kondakova, N.I. Egorova, Direktora po prizvaniju (Yakutsk, Alaas, 2014) 